\title{
PEMANFAATAN SKEMA DAYTIME MICROPHYSICS RGB HIMAWARI 8 UNTUK MENDETEKSI AWAN CUMULUS POTENSIAL DALAM KEGIATAN TEKNOLOGI MODIFIKASI CUACA
}

\author{
Utilization of the Himawari 8 Microphysic RGB Daytime Scheme to Detect \\ Potential Cumulus Clouds in Weather Modification Technology Activities
}

\author{
Bony Septian Pandjaitan ${ }^{1,2)^{*}}$, Asri Rachmawati,3), Rahmat Hidayat ${ }^{1)}$, Samba Wirahma ${ }^{4)}$, \\ Adinda Dara Vahada ${ }^{2}$
}

1) Departemen Geofisika dan Meteorologi, Institut Pertanian Bogor, Jl. Meranti, Kampus IPB Darmaga, Bogor

2) Sub Bidang Pengelolaan Citra Satelit Cuaca, Badan Meteorologi Klimatologi dan Geofisika, Jl. Angkasa I No.2 Kemayoran, Jakarta Pusat, DKI Jakarta

3) Stasiun Klimatologi Dramaga Bogor, BMKG, Jl. Tambakan, Situgede, Kota Bogor, Jawa Barat 4) Balai Besar Teknologi Modifikasi Cuaca - Badan Pengkajian dan Penerapan Teknologi, Gedung Ir. Mohammad Soebagio, GEOSTECH (820), Kawasan PUSPIPTEK, Serpong, Tangerang Selatan

*E-mail: bonyseptian89@gmail.com

\begin{abstract}
Intisari
Awan cumulus potensial, dalam kegiatan Teknologi Modifikasi Cuaca (TMC) merupakan awan target semai untuk menghasilkan hujan. Selama ini, penentuan kemunculan awan cumulus potensial biasanya didasarkan pada pengamatan radar cuaca dan pengamatan kanal tunggal satelit maupun beberapa kombinasi kanal satelit yang terpisah-pisah. Keberadaan Satelit Geostasioner Himawari 8 dengan frekuensi observasi tiap 10 menit dan memiliki banyak kanal panjang gelombang menawarkan potensi baru untuk mengamati dinamika awan. Pada artikel ini, penulis mencoba menggunakan skema daytime microphysics RGB Himawari 8 untuk mendeteksi kemunculan dan perkembangan awan cumulus potensial pada wilayah TMC di Kalimantan Barat pada bulan Agustus 2018. Berdasarkan hasil penelitian, terlihat bahwa terdapat karakter awan cumulus potensial seperti yang ditunjukkan oleh hasil klasifikasi dari skema daytime microphysics RGB Himawari 8 pada rute semai pesawat TMC. Selain itu, selama 4 hari kegiatan TMC, terlihat bahwa skema daytime microphysics RGB Himawari 8 dapat mendeteksi awal kemunculan awan cumulus potensial dengan selang waktu 1 hingga 2 jam lebih awal sebelum pesawat TMC terlihat sampai ke lokasi awan cumulus potensial tersebut. Sehingga, skema daytime microphysics RGB Himawari 8 bisa dicoba sebagai panduan informasi pelengkap data radar cuaca bagi pesawat TMC untuk menentukan lokasi awan cumulus potensial.
\end{abstract}

Kata Kunci: Cumulus, Modifikasi Cuaca, Daytime Microphysics RGB, Satelit Himawari 8.

\begin{abstract}
Potential cumulus clouds, in Weather Modification Technology (TMC) activities are seedling cloud targets to produce rain. During this time, the determination of the appearance of a potential cumulus cloud is usually based on weather radar observations and observations of single satellite channels as well as several separate satellite channel combinations. The existence of the Himawari 8 Geostationary Satellite with an observation frequency every 10 minutes and has many wavelength channels offers new potential for observing cloud dynamics. In this paper, the author tried to use the Himawari 8 RGB daytime microphysics scheme to detect the emergence and development of potential cumulus clouds in the TMC region in West Kalimantan in August 2018. Based on the research results, it appears that there are potential cumulus cloud character traits, as shown by the classification results of the scheme daytime microphysics RGB Himawari 8 on the TMC aircraft seedling route. In addition, during the five days of TMC activities, it was seen that the Himawari 8 RGB microphysics daytime scheme could detect the beginning of the appearance of potential cumulus clouds at intervals of 1 to 2 hours before the TMC aircraft was seen up to the location of the potential cumulus clouds. Thus, the Himawari 8 microphysics RGB daytime scheme can be tried as a supplementary information guide on weather radar data for TMC aircraft to determine the location of potential cumulus clouds.
\end{abstract}

Keywords: Cumulus, Weather Modification, Daytime Microphysics RGB, Himawari 8 Satellite. 


\section{PENDAHULUAN}

Teknologi Modifikasi Cuaca (TMC) merupakan suatu bentuk campur tangan manusia untuk mendapatkan kondisi cuaca yang diinginkan. TMC biasanya dilakukan dengan melakukan intervensi pada sistem awan yang akan menghasilkan suatu kondisi cuaca tertentu. Di Indonesia, kegiatan TMC dilakukan dengan tujuan untuk menambah atau mengurangi curah hujan untuk kepentingan mitigasi bencana maupuan kepentingan sektor lain. Kegiatan TMC untuk menambah curah hujan dilakukan pada periode curah hujan yang minim maupun untuk upaya memadamkan kebakaran hutan dan lahan (Harsoyo, 2012; Wirahma et al, 2014).

Terdapat beberapa metode dalam kegiatan TMC, yang salah satunya adalah penyemaian awan cumulus potensial dengan menyebarkan partikel higroskopik yang dibawa menggunakan pesawat. Partikel higroskopis sangat membantu memperbesar ukuran butir awan karena sifatnya dapat meningkatkan efisiensi tumbukan dan penggabungan (collision and coalescense) atau proses pembentukan es (ice nucleation). Hal tersebut membantu proses alamiah dalam awan menjadi lebih optimal sehingga pada akhirnya meningkatkan curah hujan (Arifian, 2002; Syaifullah, 2012; Seto, 2000). Oleh karena itu, salah satu hal penting yang perlu dalam melakukan kegiatan TMC adalah keberadaan awan cumulus potensial yang menjadi awan target untuk dilakukan penyemaian.

Mengingat peran penting awan cumulus potensial tersebut, maka pada kegiatan TMC, monitoring keberadaan awan cumulus potensial merupakan suatu dasar dalam memulai kegiatan penyemaian awan. Setelah terdeteksi kemunculan awan cumulus potensial, maka pesawat TMC akan terbang menuju koordinat dimana awan tersebut muncul, selanjutnya akan dilakukan penyemaian material higroskopis yang bertindak sebagai inti kondenasi ke dalam awan tersebut (Haryanto, 2000). Karena siklus cumulus yang dapat dengan cepat berubah, deteksi keberadaan awan dengan akurat menjadi sangat penting agar informasi tersebut dapat dimanfaatkan secara maksimal.

Pada kegiatan TMC di wilayah Indonesia, kegiatan monitoring keberadan awan cumulus potensial biasa dilakukan dengan mengamati produk radar cuaca (Syaifullah, 2011; Syaifullah, 2012; Renggono, 2015). Secara prinsip, radar cuaca yang digunakan di wilayah Indonesia merupakan precipitation radar dan banyak yang berjenis single polarization dimana gelombang yang dikeluarkan secara umum bertujuan untuk mendeteksi presipitasi atau tetes hujan (rain drop) dalam awan yang secara teori memiliki ukuran sekitar $2 \mathrm{~mm}$, dimana jauh lebih besar dibandingkan ukuran tetes awan (cloud drop) sekitar 0,02 $\mathrm{mm}$ pada awan (Wallace dan Hobbs, 2005) yang sulit dideteksi oleh radar cuaca.
Sehingga, apabila terdapat wilayah yang muncul nilai reflektivitas (dbz) pada citra radar cuaca, maka wilayah tersebut secara umum merupakan wilayah dengan awan konvektif dewasa yang mengandung tetes hujan (rain drop), ataupun wilayah yang sedang terjadi hujan.

Selain menggunakan radar cuaca dalam pemantauan awan cumulus potensial, digunakan juga satelit dengan tipe sensor optik dan memiliki orbit geostasioner seperti pada Satelit MTSAT dan Satelit Himawari 8. Satelit ini, secara prinsip mendeteksi tetes awan (cloud drop) yang terdapat pada awan cumulus potensial. Namun, hal ini masih dilakukan dengan pengamatan kanal tunggal satelit maupun menggunakan beberapa kombinasi kanal satelit, namun tidak terintegrasi seperti kajian yang dilakukan oleh Syaifullah \& Nuryanto (2016).

Perkembangan satelit penginderaan jauh geostasioner untuk mengamati dinamika cuaca sudah sangat berkembang pesat di masa ini. Keberadaan Satelit Geostasioner Himawari 8 dengan frekuensi observasi tiap 10 menit dan memiliki 16 kanal panjang gelombang, menawarkan potensi baru untuk mengamati dinamika awan di wilayah Indonesia. Berdasarkan karakteristik dari 16 kanal panjang gelombang Himawari 8, terdapat beberapa kanal yang ditujukan untuk mendeteksi properti dalam awan. Hal ini menyebabkan beberapa metode yang sebelumnya tidak bisa digunakan pada data satelit geostasioner di wilayah Asia, termasuk Indonesia (misalnya: MTSAT, dan Fengyun seri lama), sekarang berpotensi bisa diterapkan menggunakan data Satelit Geostasioner Himawari 8. Salah satu metode yang bisa diterapkan adalah metode komposit RGB pada skema daytime microphysics RGB menggunakan data multi kanal. Skema ini sudah umum digunakan untuk mendeteksi property awan pada periode daytime di wilayah Benua Eropa dan Afrika menggunakan Satelit Meteosat dan wilayah Benua Amerika menggunakan Satelit GOESS (JMA, 2015).

Berdasarkan beberapa penjelasan di atas, maka pada artikel ini penulis mencoba menggunakan skema daytime microphysics RGB Himawari 8 dengan tujuan untuk mendeteksi kemunculan dan perkembangan awan cumulus potensial pada wilayah dimana terdapat kegiatan TMC.

\section{METODE}

\subsection{Data}

Penelitian dilakukan dengan mengambil studi kasus pada kegiatan Teknologi Modifikasi Cuaca (TMC) yang dilakukan di wilayah Kalimantan Barat. Untuk periode penelitian, penulis batasi dalam periode 27-30 Agustus 2018. Hal ini dilakukan untuk menyesuaikan dengan periode kegiatan TMC di lokasi tersebut. 
Penelitian dilakukan dengan mengumpulkan data track pesawat TMC saat terbang melakukan kegiatan TMC dengan format data .shp. Banyak data yang digunakan disesuaikan dengan periode penelitian yang telah ditetapkan sebelumnya. Data ini berisi informasi titik koordinat beserta waktu pesawat mulai dari awal terbang, melakukan penyemaian awan, hingga kembali mendarat.

Selain itu, dilakukan pengumpulan data Satelit Himawari 8 dengan format sataid (.z) sebanyak 16 kanal tiap 10 menit mulai jam 07.0010.00 WIB tiap hari selama periode penelitian. Data satelit ini merupakan data level 1B yang telah terkoreksi geometrik maupun radiometrik yang berisi nilai suhu kecerahan (brightness temeperature) untuk rumpun kanal Inframerah dan nilai reflektansi untuk rumpun kanal sinar tampak. Setelah itu dilakukan pengumpulan data citra produk CMAX radar cuaca Pontianak.

\subsection{Alur Pengolahan Data}

Setelah melakukan pengumpulan semua data track pesawat TMC dalam format .shp, maka dilakukan converting dari data format .shp menjadi format .csv menggunakan perangkat lunak global mapper. Selanjutnya data track pesawat TMC dalam format .csv yang berisi informasi titik koordinat beserta waktu selama pesawat melakukan kegiatan TMC tersebut diplot pada perangkat lunak Mcidas$\mathrm{V}$.

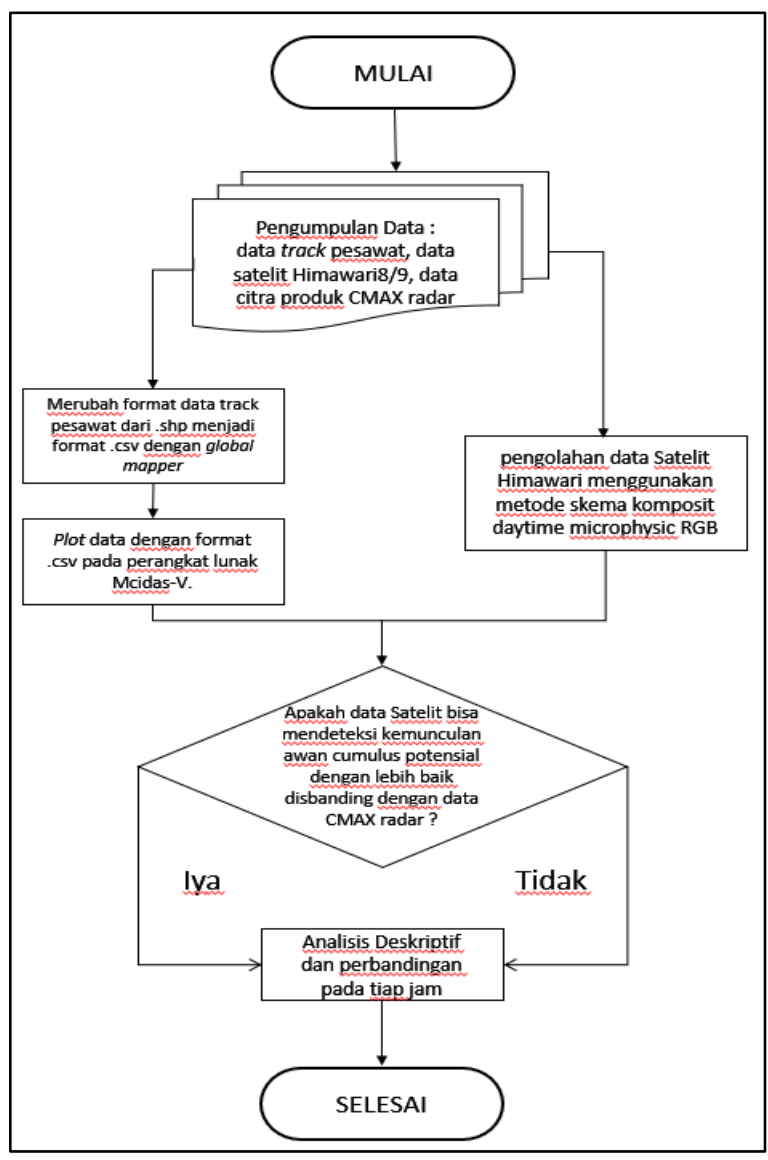

Gambar 1. Diagram alur pengolahan data.
Hasil plot track pesawat selama melakukan kegiatan TMC per hari tersebut digunakan sebagai informasi wilayah dimana pesawat TMC menyemai awan cumulus potensial. Selain itu, didapatkan juga informasi jam saat awan melakukan penyemaian pada awan cumulus potensial. Proses pengolahan data ini dilakukan untuk semua data track pesawat TMC per hari untuk seluruh periode penelitian.

Setelah dilakukan pengumpulan data satelit Himawari 8 seperti yang telah dijelaskan sebelumnya, maka dilakukan pengolahan data kanal panjang gelombang 0,86 $\mu \mathrm{m}$ (band 4/ N1), kanal panjang gelombang 3,9 $\mu \mathrm{m}$ (band $7 / 14$ ), dan kanal panjang gelombang 10,4 $\mu \mathrm{m}$ (band 13/IR) menggunakan metode skema komposit daytime microphysics RGB. Proses pengolahan untuk mendapatkan citra komposit daytime microphysics RGB ini dilakukan untuk semua data 3 kanal tersebut selama periode penelitian.

\subsection{Metode Analisis}

Setelah didapatkan hasil plot track pesawat TMC tiap hari selama melakukan penyemaian awan dan hasil citra komposit daytime microphysics RGB tiap hari selama periode penelitian, lalu dilakukan analisis deskriptif untuk mengetahui karakteristik awan yang terdeteksi dari citra komposit daytime microphysics RGB di dalam wilayah yang dilewati pesawat TMC tiap hari selama periode penelitian. Selanjutnya dilakukan investigasi pada jam berapakah awan cumulus potensial mulai muncul di citra komposit daytime microphysics RGB beserta perkembangannya. Periode jam awal kemunculan awan cumulus potensial berdasarkan citra daytime microphysics RGB ini akan dibandingkan dengan citra produk cmax radar cuaca periode saat pesawat TMC melakukan penyemaian awan yang didapatkan dari informasi track penerbangan pesawat tiap hari selama periode penelitian.

Analisis tersebut dilakukan untuk mengetahui sejauh mana skema daytime microphysics RGB dari satelit Himawari 8 bisa mendeteksi kemunculan awan cumulus potensial dibandingkan dengan hasil menggunakan data radar cuaca. Hal ini bisa dilakukan dengan menggunakan pendekatan asumsi bahwa secara operasional, pesawat TMC baru akan terbang untuk melakukan penyemaian awan jika awan cumulus potensial telah terdeteksi berdasarkan citra radar cuaca.

\subsection{Skema Daytime Microphysics $R G B$}

Teknik komposit RGB (red green blue) merupakan sebuah teknik penyajian suatu informasi dengan menggunakan konsep citra/gambar berwarna yang berasal dari gabungan 3 warna utama cahaya, yaitu merah (red), hijau (green), biru (blue). Kombinasi dari 3 warna primer tersebut menghasilkan warna-warna turunan (secondary colour) kuning, magenta, cyan, coklat, hitam, dan putih (Comet, 2013) seperti yang terdapat pada Gambar 2. 


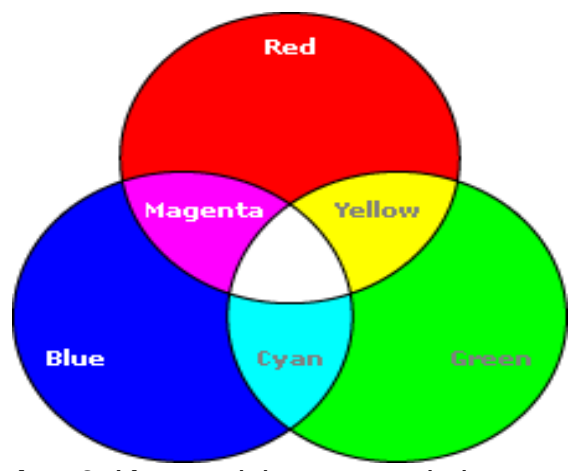

Gambar 2. Komposisi warna pada konsep citra RGB

Konsep citra RGB telah lama digunakan dalam pengolahan citra satelit penginderaan jauh. Teknik ini berfungsi untuk menampilkan lebih dari satu informasi yang diperoleh dari masing-masing kanal panjang gelombang satelit ke dalam bentuk satu tampilan. Tampilan warna akhir tersebut berasal dari setiap kanal atau kombinasi kanal panjang gelombang satelit yang dimasukkan dalam komponen warna merah (red), hijau (green), dan biru (blue). WMO (World Meteorological Organization) telah merekomendasikan sekitar 9 skema komposit RGB yang bisa digunakan untuk menampilkan informasi gabungan di bidang meteorologi menggunakan data satelit cuaca (Comet, 2013).

Salah satu skema komposit RGB yang dapat digunakan untuk memantau kondisi awan dan cuaca pada daytime adalah skema komposit daytime microphysics RGB. Skema ini merupakan teknik pengolahan citra RGB dengan komponen merah (red) menggunakan data nilai kanal panjang gelombang 0,86 $\mu \mathrm{m}$ (band 4/N1). Komponen hijau (green) menggunakan kanal panjang gelombang $3,9 \mu \mathrm{m}$ (band 7//4). Komponen biru (b/ue) menggunakan kanal panjang gelombang 10,4 $\mu \mathrm{m}$ (band 13/IR).

Tabel 1 menunjukkan pengaturan nilai minimum atau maksimum Brightness Temperature (Reflektansi) yang digunakan untuk pada skema RGB ini. Selain itu terdapat juga informasi yang diperoleh pada tiap kanal pada skema daytime microphysic RGB.

Nilai reflektansi kanal $0.86 \mu \mathrm{m}$ (band 4/N1) digunakan untuk mendapatkan informasi ketebalan optik awan dan jumlah air awan dan jumlah es awan. Nilai reflektansi 3,9 $\mu \mathrm{m}$ (band 7//4) memberikan pendekatan informasi kualitatif untuk ukuran dan fase partikel awan.

Nilai suhu kecerahan 10,8 $\mu \mathrm{m}$ (band 13/IR) digunakan untuk memberikan pendekatan informasi tentang ketinggian suatu partikel atau awan yang terdeteksi satelit. Kombinasi dari masing-masing informasi yang diberikan oleh kanal panjang gelombang pada komponen merah (red), hijau (green), dan biru (blue) pada skema daytime microphysic RGB ini akan menghasilkan komposit warna beserta informasi fisis yang diperoleh seperti yang terdapat pada Gambar 3 dan dijelaskan secara rinci pada Lensky \& Rosenfeld (2008).
Tabel 1. Pengaturan Nilai Minimum/Maksimum untuk Nilai Brightness Temperature (Reflektansi), Gradasi Citra Grayscale dan Citra Berwarna, serta Informasi Tiap Kanal untuk Skema Daytime Microphysic RGB (Lensky \& Rosenfeld, 2008).

\begin{tabular}{|c|c|c|c|c|c|c|c|c|}
\hline \multirow[t]{2}{*}{ Kanal } & \multicolumn{2}{|c|}{$\begin{array}{c}\text { Nilai } \\
\text { Brightness } \\
\text { Temperature } \\
\text { / Reflektansi }\end{array}$} & \multicolumn{2}{|c|}{$\begin{array}{l}\text { Gradasi Citra } \\
\text { Grayscale }\end{array}$} & \multicolumn{2}{|c|}{$\begin{array}{c}\text { Gradasi Citra } 3 \\
\text { warna }\end{array}$} & \multicolumn{2}{|c|}{$\begin{array}{c}\text { Informasi Fisis } \\
\text { Tiap Kanal }\end{array}$} \\
\hline & Min. & Maks. & Min. & Maks. & Min. & Maks. & Min. & Maks. \\
\hline $\begin{array}{c}0,86 \mu \mathrm{m} \\
\text { (band } 4 / \\
\mathrm{N} 1 \text { ) }\end{array}$ & $0 \%$ & $100 \%$ & $\begin{array}{l}\text { Gelap/ } \\
\text { hitam }\end{array}$ & $\begin{array}{l}\text { Terang } \\
\text { /putih }\end{array}$ & Gelap & Merah & $\begin{array}{l}\text { Awan } \\
\text { Tipis }\end{array}$ & $\begin{array}{l}\text { Awan } \\
\text { Tebal }\end{array}$ \\
\hline $\begin{array}{l}3,9 \mu \mathrm{m} \\
\text { (band } 7 \text { / } \\
\text { I4) }\end{array}$ & $0 \%$ & $60 \%$ & $\begin{array}{l}\text { Gelap/ } \\
\text { hitam }\end{array}$ & $\begin{array}{l}\text { Terang } \\
\text { /putih }\end{array}$ & Gelap & Hijau & \begin{tabular}{|c|} 
Partikel \\
kecil \\
pada \\
cloud \\
\end{tabular} & $\begin{array}{c}\text { Cloud } \\
\text { water / } \\
\text { ice besar }\end{array}$ \\
\hline $\begin{array}{c}10,4 \mu \mathrm{m} \\
\text { (band } 13 / \\
\text { IR) }\end{array}$ & 50 & -70 & $\begin{array}{l}\text { Terang } \\
\text { /putih }\end{array}$ & $\begin{array}{c}\text { Gelap/h } \\
\text { itam }\end{array}$ & Biru & Gelap & $\begin{array}{c}\text { Puncak } \\
\text { Awan } \\
\text { panas / } \\
\text { paras } \\
\text { rendah }\end{array}$ & $\begin{array}{c}\text { Puncak } \\
\text { Awan } \\
\text { dingin / } \\
\text { paras } \\
\text { tinggi }\end{array}$ \\
\hline
\end{tabular}

Proses pengolahan pada skema komposit daytime microphysic RGB ini dimulai dengan mengolah data 3 kanal $(0,86 \mu \mathrm{m} ; 3,9 \mu \mathrm{m} ; 10,4 \mu \mathrm{m})$ menjadi citra grayscale dengan menetapkan nilai minimum dan maksimum pada masing-masing kanal seperti pada Gambar 4(a)-4(c).

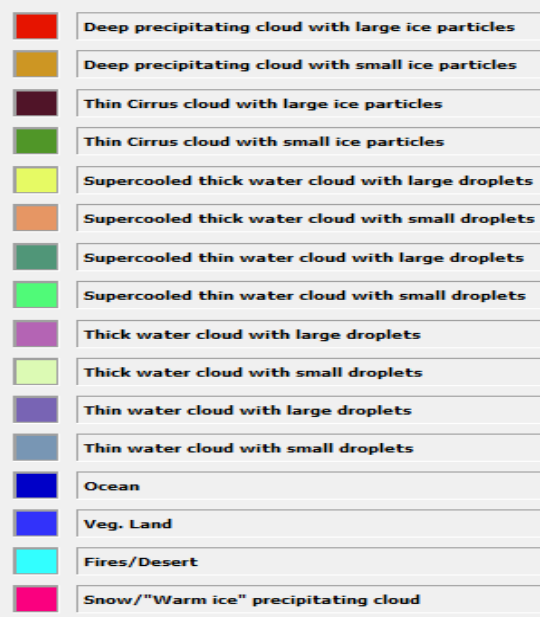

Gambar 3. Komposisi warna komposit Daytime Micophysic RGB beserta informasi fisis yang dihasilkan (Lensky \& Rosenfeld, 2008).

Citra grayscale dari 3 kanal tersebut selanjutnya ditransformasikan menjadi citra merah (red) untuk kanal 0,86 $\mu \mathrm{m}$, citra hijau (green) untuk kanal 3,9 $\mu \mathrm{m}$, dan citra biru (blue) untuk kanal 10,4 $\mu \mathrm{m}$ seperti pada Gambar 4(d)-4(f). Setelah itu, dilakukan proses komposit dari komponen merah (red), hijau (green), dan biru (blue) lalu didapatkan citra komposit RGB yang berisi beberapa warna seperti pada gambar $4(\mathrm{~g})$.

Proses pengolahan skema komposit daytime microphysic RGB menggunakan perangkat lunak SATAID GMSLPD. Perangkat lunak ini dapat secara langsung mengolah data level 1B satelit Himawari 8 menjadi citra 9 skema komposit RGB, termasuk skema komposit daytime microphysic RGB (JMA, 2015; Tanaka, 2009). 


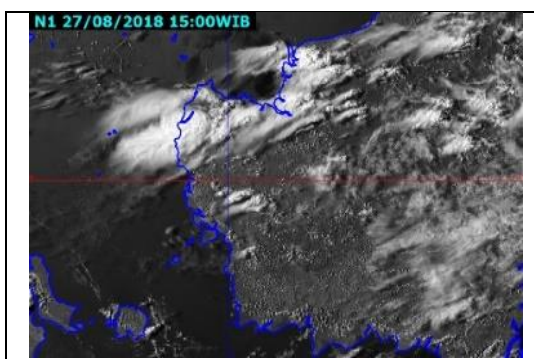

(a)

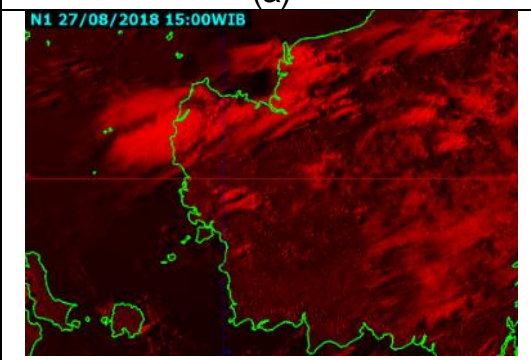

(d)

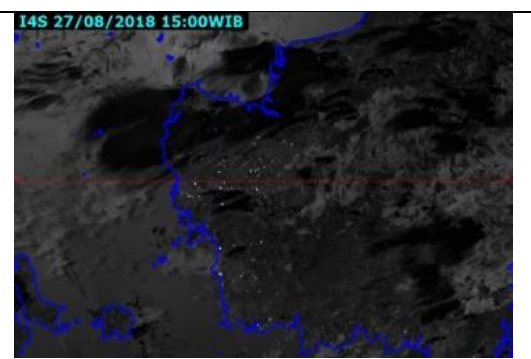

(b)

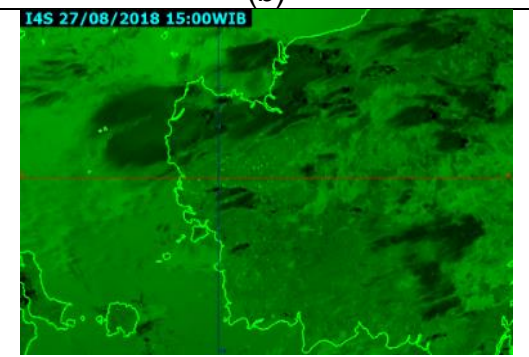

(e)

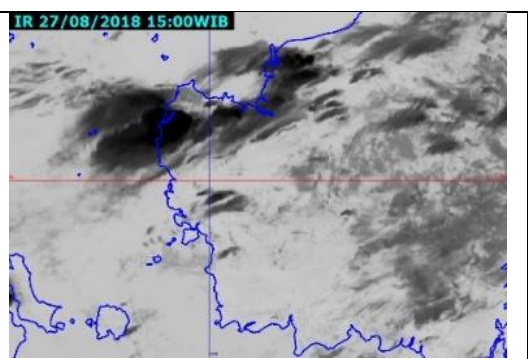

(c)

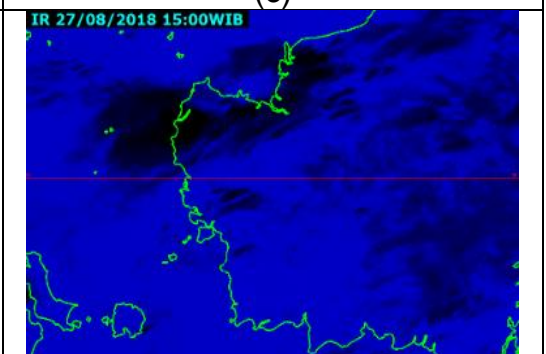

(f)

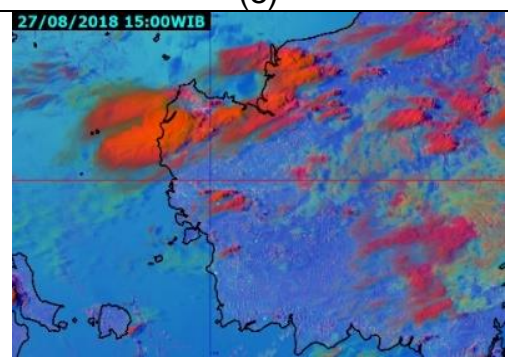

(g)

Gambar 4. Proses pengolahan citra skema komposit daytime microphysic RGB yang dimulai dengan menghasilkan: (a) citra grayscale kanal 0,86 $\mu \mathrm{m}$; (b) citra grayscale kanal 3,9 $\mu \mathrm{m}$; (c) citra grayscale kanal 10,4 $\mu \mathrm{m}$; lalu dilanjutkan dengan menghasilkan: (d) citra merah kanal 0,86 $\mu \mathrm{m}$; (e) citra hijau kanal $3,9 \mu \mathrm{m}$; (f) citra biru kanal 10,4 $\mu \mathrm{m}$; dan akhirnya didapatkan (g) citra komposit daytime microphysic RGB.

\section{HASIL DAN PEMBAHASAN}

\subsection{Komposit Track Pesawat TMC}

Sepanjang periode penelitian mulai tanggal 27-30 Agustus 2018, terlihat bahwa kegiatan modifikasi cuaca yang dilakuan di wilayah Kalimantan Barat meliputi dari wilayah Pontianak hingga wilayah utara dan timur dari Pontianak seperti yang telihat pada Gambar 5(a). Kegiatan TMC ini dilakukan untuk mengatasi banyaknya titik panas yang muncul di wilayah Kalimantan Barat seperti yang terlihat pada Gambar 5(b).

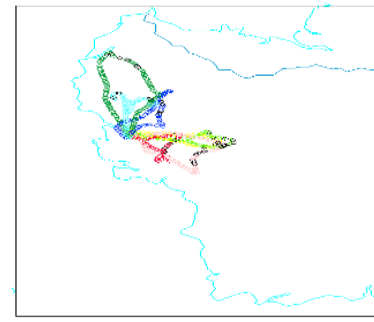

(a)

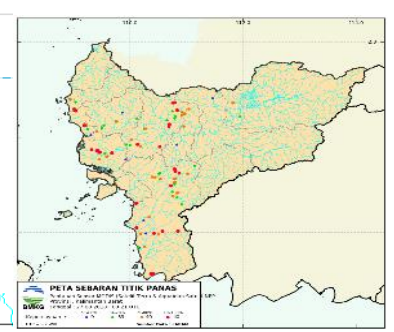

(b)
Gambar 5. (a) Gabungan track pesawat saat melakukan proses penyemaian awan cumulus potensial selama durasi penelitian; (b) peta titik panas di wilayah Kalimantan Barat.
Berdasarkan Gambar 5(a) dan 5(b), terlihat bahwa sepanjang periode kajian kegiatan modifikasi cuaca yang dilakuan di wilayah Kalimantan Barat yang diambil penulis yaitu tanggal 27-30 Agustus 2018, rute penyemaian awan masih belum seluruhnya meliputi wilayah kemunculan titik panas.

\subsection{Analisis Distribusi Awan pada TMC Tanggal 27 Agustus 2018}

Pada tanggal 27 Agustus 2018 ini, berdasarkan tabel 2, terlihat bahwa pesawat lepas landas sekitar pukul 14.15 WIB. Di saat yang bersamaan, jika kita tinjau citra daytime microphysic RGB pada gambar 6(b) di wilayah koordinat $A$ hingga $E$ yang merupakan titik koordinat penyemaian, terlihat adanya awanawan dengan karakteristik seperti awan konvektif yang sudah memiliki tinggi puncak yang menjulang tinggi seperti kategori pada gambar 3 . Namun hal ini belum terdeteksi oleh produk cmax radar cuaca seperti yang terlihat pada gambar 6(e). Walaupun begitu citra cmax radar tersebut mendeteksi echo awan pada sebelah tenggara koordinat $\mathrm{A}-\mathrm{E}$, sedangkan dari citra daytime microphysic RGB, di wilayah tersebut juga terdeteksi awan deep convective kuat yang sudah 
merupakan ciri-ciri cumulonimbus dengan updraft yang kuat seperti yang dijelaskan pada gambar 3 .

Kondisi awan saat pesawat menebarkan bahan semai pada koordinat $A$ sampai $\mathrm{K}$ mulai jam 14.57-15.11 WIB seperti terlihat pada tabel 2 diwakili oleh gambar 6(c) dan 6(f).

Pada Gambar 6(c) menunjukkan bahwa saat pesawat melakukan penyemaian, maka kondisi awan yang ada telah masuk kategori awan cumulonimbous fase dewasa seperti karakteristik pada gambar 3 dimana pada fase ini selain terdapat updraft, juga terdapat downdraft sehingga dimungkinkan sedang terjadi hujan (Lensky \& Rosenfeld, 2008). Hal ini terlihat juga pada Gambar 6(f), dimana produk cmax radar menunjukkan adanya nilai 40-50 dbz.

Berdasarkan analisis, citra daytime microphysic RGB pada periode sebelum pesawat take off, bahwa awan cumulus potensial mulai terdeteksi pada sekitar jam 13.00-13.30 WIB di titik koordinat semai A-K seperti yang terlihat pada Gambar 6(a). Namun awan cumulus potensial ini belum terdeteksi pada citra radar cuaca pada Gambar 6(d).

Berdasarkan deret waktu citra daytime microphysics RGB mulai dari cumulus potensial terdeteksi hingga saat penyemaian yang diwakili oleh Gambar 6(a)-6(c), terlihat di wilayah koordinat $\mathrm{A}-\mathrm{K}$ terjadi proses pertumbuhan awan konvektif berupa awan cumulus potensial hingga menjadi awan cumulonimbus. Proses pertumbuhan awan konvektif ini tidak semua nya tertangkap oleh citra cmax radar cuaca seperti pada Gambar 6(d) - 6(f).

Tabel 2. Koordinat Pesawat saat Melakukan Penyemaian Tanggal 27 Agustus 2018.

\begin{tabular}{|c|c|c|c|c|}
\hline $\begin{array}{c}\text { Way } \\
\text { point }\end{array}$ & Tanggal & $\begin{array}{c}\text { Jam } \\
\text { (WIB) }\end{array}$ & Lintang & Bujur \\
\hline Start & $27-A u g-2018$ & $14: 15$ & -0.151 & 109.406 \\
\hline A & $27-A u g-2018$ & $14: 57$ & -0.344 & 110.079 \\
\hline B & $27-A u g-2018$ & $14: 58$ & -0.349 & 110.129 \\
\hline C & $27-A u g-2018$ & $15: 00$ & -0.328 & 110.195 \\
\hline D & $27-A u g-2018$ & $15: 01$ & -0.302 & 110.238 \\
\hline E & $27-A u g-2018$ & $15: 02$ & -0.308 & 110.28 \\
\hline F & $27-A u g-2018$ & $15: 04$ & -0.279 & 110.27 \\
\hline G & $27-A u g-2018$ & $15: 05$ & -0.235 & 110.276 \\
\hline H & $27-A u g-2018$ & $15: 07$ & -0.186 & 110.221 \\
\hline I & $27-A u g-2018$ & $15: 08$ & -0.167 & 110.183 \\
\hline J & $27-A u g-2018$ & $15: 10$ & -0.132 & 110.097 \\
\hline K & $27-A u g-2018$ & $15: 11$ & -0.131 & 110.059 \\
\hline Finish & $27-A u g-2018$ & $15: 33$ & -0.151 & 109.406 \\
\hline
\end{tabular}

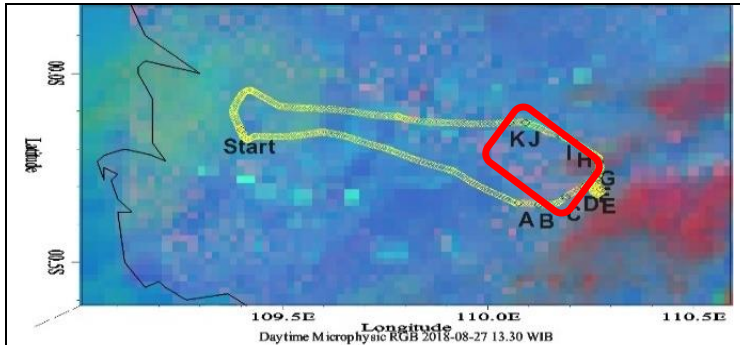

(a)

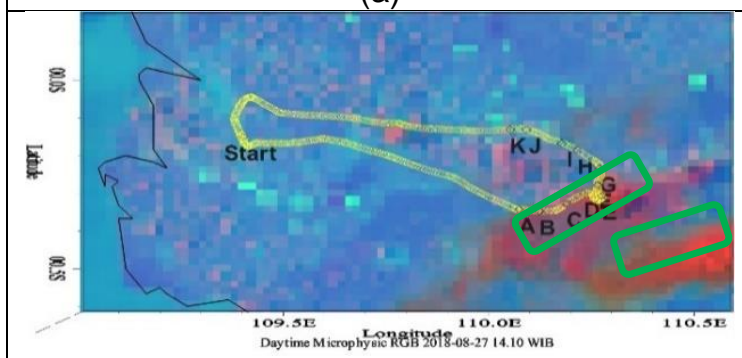

(b)

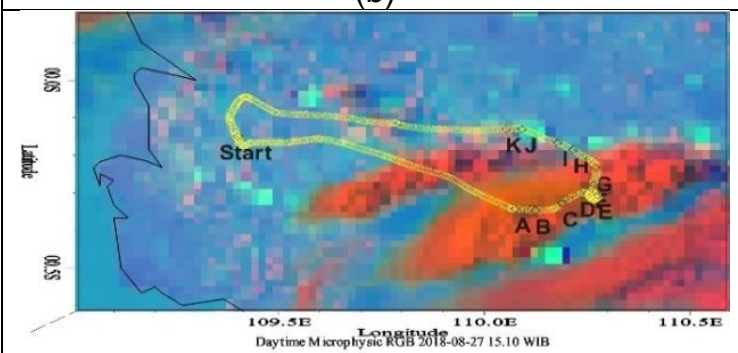

(c)

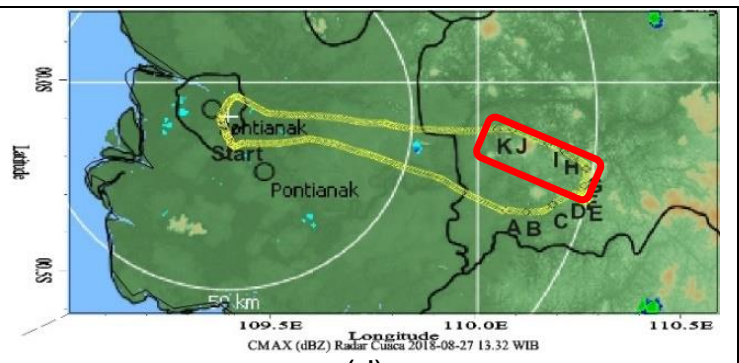

(d)

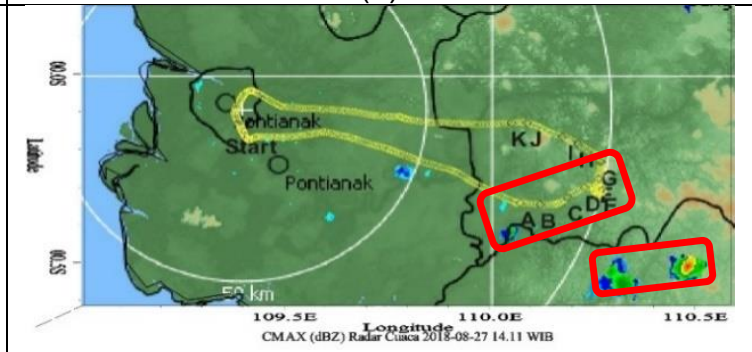

(e)

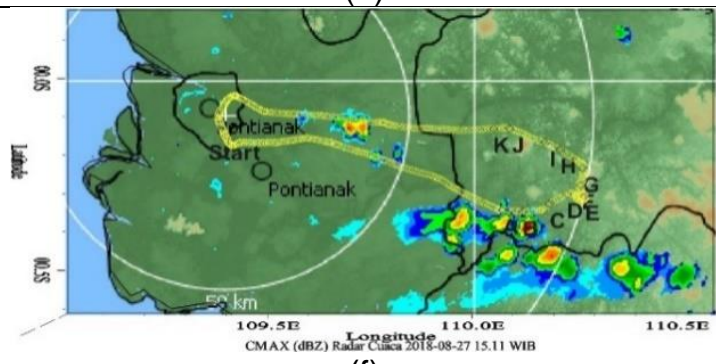

(f)

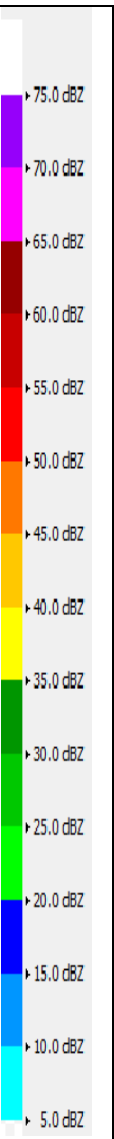

Gambar 6. Kondisi awan pada kegiatan TMC tanggal 27 Agustus 2018 yang terdeteksi dari (a)-(c) produk day microphysic RGB Himawari 8; sedangkan (d)-(f) produk cmax radar cuaca. (Keterangan warna RGB dijelaskan pada gambar 3, keterangan warna CMAX terletak di kanan gambar) 


\subsection{Analisis Distribusi Awan pada TMC Tanggal 28 Agustus 2018}

Pada kegiatan TMC tanggal 28 Agustus 2018 , terdapat 2 sorti penerbangan seperti yang terlihat pada tabel 3 untuk sorti pertama dan tabel 4 untuk sorti kedua. Penerbangan sorti pertama dimulai dengan pesawat take off pada sekitar jam 13.08 WIB. Pada saat take off, berdasarkan citra daytime microphysic RGB pada gambar $7(\mathrm{~b})$, maka kondisi awan di wilayah koordinat $A$ hingga $\mathrm{N}$ terlihat adanya awan-awan cumulus potensial, sedangkan berdasarkan citra cmax radar cuaca belum terdeteksi seperti yang terlihat pada gambar $7(\mathrm{~g})$. Nilai echo awan konvektif pada citra radar terdeteksi di sebelah selatan rute koordinat A-N. Hal ini juga terlihat pada citra daytime microphysic RGB.

Kondisi awan saat pesawat menebarkan bahan semai pada koordinat A sampai K pada jam 13.46-14.04 WIB seperti terlihat pada tabel 2 diwakili oleh gambar 7(c) dan 7(h). Pada gambar 7(c) menunjukkan bahwa saat pesawat melakukan penyemaian, terdapat awan cumulus potensial dan awan cumulonimbus seperti karakteristik pada gambar 3 . Hal ini terlihat juga pada gambar 7(h), dimana produk cmax radar menunjukkan adanya awan cumulonimbus sel tunggal dengan nilai 35-45 dbz. Jika dilihat wilayah yang jauh di sebelah selatan rute semai, maka terdeteksi kumpulan awan konvektif cumulonimbus yang merupakan awan konvektif hasil pertumbuhan awan cumulus pada jam-jam sebelumnya di wilayah tersebut.

Berdasarkan analisis, citra daytime microphysic RGB pada periode sebelum pesawat take off pada sorti 1 , maka kemunculan awan cumulus potensial mulai terdeteksi pada sekitar jam 12.30 WIB di titik koordinat semai A-N seperti yang terlihat pada gambar 7(a). Namun awan cumulus potensial ini belum terdeteksi pada citra radar cuaca pada gambar $7(\mathrm{f})$.

Pada penerbangan sorti 2 , take off pesawat dilakukan pada sekitar jam 15.03 WIB. Pada saat take off, berdasarkan citra daytime microphysic RGB pada gambar $7($ d), kondisi awan di wilayah koordinat $\mathrm{A}-\mathrm{J}$, terlihat kondisi awan yang ada mulai menuju ke kategori awan cumulonimbus seperti karakteristik pada gambar 3. Hal ini terlihat juga pada gambar 7 (i), dimana produk cmax radar menunjukkan adanya nilai 40-50 dbz.

Selanjutnya, kondisi awan saat pesawat menebarkan bahan semai pada koordinat $A$ - $K$ pada jam 15.29-15.41 WIB seperti terlihat pada tabel 2 diwakili oleh gambar $7(\mathrm{e})$ dan 7(j). Pada gambar 7(e) menunjukkan bahwa pada saat pesawat melakukan penyemaian, sudah terdapat awan cumulonimbus fase dewasa seperti karakteristik pada gambar 3 dimana pada fase ini selain terdapat updraft, juga terdapat downdraft sehingga kemungkinan sedang terjadi hujan. Hal ini terlihat juga pada gambar $7(j)$, dimana produk cmax radar menunjukkan adanya nilai 40-50 dbz.

Berdasarkan analisis, citra daytime microphysic RGB pada periode sebelum pesawat take off pada sorti 2, maka kemunculan awan cumulus potensial mulai terdeteksi pada sekitar jam 13.10 WIB di titik koordinat semai A-J seperti yang terlihat pada gambar 7(b). Namun awan cumulus potensial ini belum terdeteksi pada citra radar cuaca pada gambar $7(\mathrm{~g})$.

Berdasarkan deret waktu citra daytime microphysics RGB mulai dari cumulus potensial terdeteksi hingga saat penyemaian yang diwakili oleh gambar $7(\mathrm{a})-7(\mathrm{e})$, terlihat di koordinat A-N pada sorti 1 dan A-J pada sorti 2 terjadi proses pertumbuhan awan konvektif berupa awan cumulus potensial hingga menjadi awan cumulonimbus. Proses pertumbuhan awan konvektif ini tidak semuanya tertangkap oleh citra cmax radar cuaca seperti pada gambar $7(\mathrm{f})-7(\mathrm{j})$.

Tabel 3. Koordinat Pesawat saat Melakukan Penyemaian Sorti 1 Tanggal 28 Agustus 2018.

\begin{tabular}{|c|c|c|c|c|}
\hline $\begin{array}{c}\text { Way } \\
\text { point }\end{array}$ & Tanggal & $\begin{array}{c}\text { Jam } \\
(\mathrm{WIB})\end{array}$ & Lintang & Bujur \\
\hline Start & 28 -Aug-2018 & $13: 08$ & -0.151 & 109.406 \\
\hline A & 28 -Aug-2018 & $13: 46$ & -0.096 & 110.176 \\
\hline B & 28 -Aug-2018 & $13: 58$ & -0.159 & 110.198 \\
\hline C & 28 -Aug-2018 & $13: 50$ & -0.173 & 110.254 \\
\hline D & 28 -Aug-2018 & $13: 51$ & -0.184 & 110.305 \\
\hline E & 28 -Aug-2018 & $13: 52$ & -0.199 & 110.332 \\
\hline F & 28 -Aug-2018 & $13: 54$ & -0.231 & 110.409 \\
\hline G & 28 -Aug-2018 & $13: 55$ & -0.249 & 110.450 \\
\hline H & 28 -Aug-2018 & $13: 56$ & -0.270 & 110.420 \\
\hline I & 28 -Aug-2018 & $13: 58$ & -0.297 & 110.371 \\
\hline J & 28 -Aug-2018 & $13: 59$ & -0.321 & 110.325 \\
\hline K & 28 -Aug-2018 & $14: 00$ & -0.339 & 110.303 \\
\hline L & 28 -Aug-2018 & $14: 00$ & -0.353 & 110.279 \\
\hline M & 28 -Aug-2018 & $14: 04$ & -0.329 & 110.164 \\
\hline N & 28 -Aug-2018 & $14: 04$ & -0.323 & 110.127 \\
\hline Finish & 28 -Aug-2018 & $14: 30$ & -0.151 & 109.406 \\
\hline
\end{tabular}

Tabel 4. Koordinat Pesawat saat Melakukan Penyemaian Sorti 2 Tanggal 28 Agustus 2018.

\begin{tabular}{|c|c|c|c|c|}
\hline $\begin{array}{c}\text { Way } \\
\text { point }\end{array}$ & Tanggal & $\begin{array}{c}\text { Jam } \\
\text { (WIB) }\end{array}$ & Lintang & Bujur \\
\hline Start & 28-Aug-2018 & $15: 03$ & -0.151 & 109.406 \\
\hline A & 28 -Aug-2018 & $15: 29$ & -0.118 & 109.862 \\
\hline B & 28 -Aug-2018 & $15: 32$ & -0.196 & 109.880 \\
\hline C & 28 -Aug-2018 & $15: 32$ & -0.226 & 109.856 \\
\hline D & 28 -Aug-2018 & $15: 33$ & -0.228 & 109.855 \\
\hline E & 28 -Aug-2018 & $15: 34$ & -0.285 & 109.805 \\
\hline F & 28 -Aug-2018 & $15: 36$ & -0.363 & 109.754 \\
\hline G & 28 -Aug-2018 & $15: 38$ & -0.429 & 109.749 \\
\hline H & 28 -Aug-2018 & $15: 39$ & -0.469 & 109.735 \\
\hline I & 28 -Aug-2018 & $15: 40$ & -0.499 & 109.711 \\
\hline J & 28 -Aug-2018 & $15: 41$ & -0.546 & 109.686 \\
\hline Finish & 28 -Aug-2018 & $16: 07$ & -0.151 & 109.406 \\
\hline
\end{tabular}




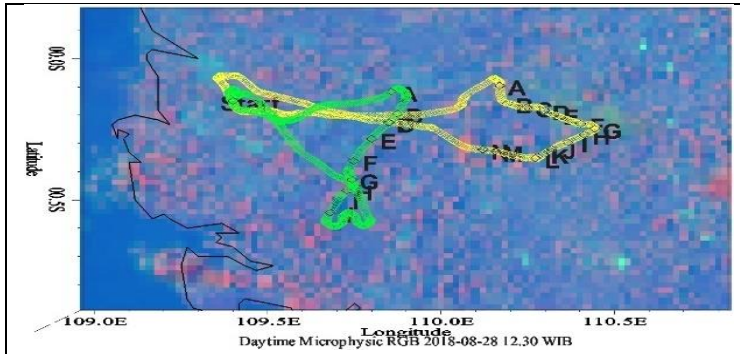

(a)

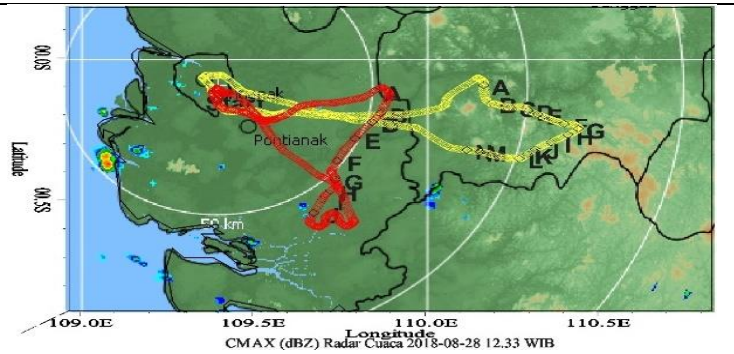

(f)

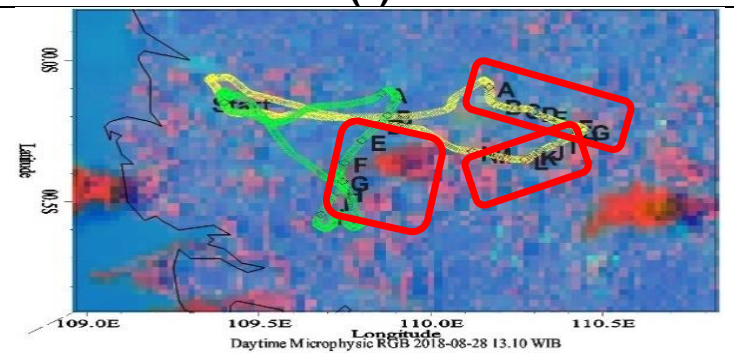

(b)

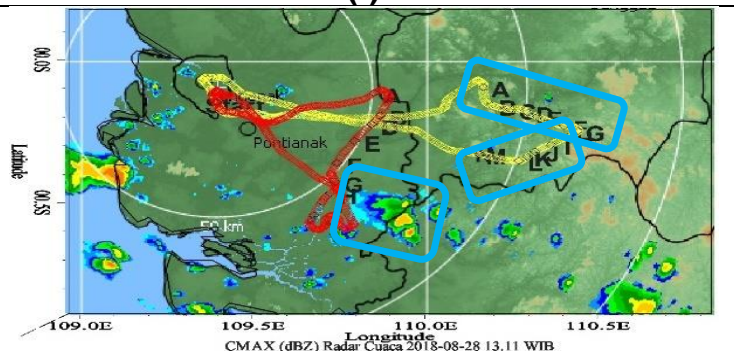

(g)

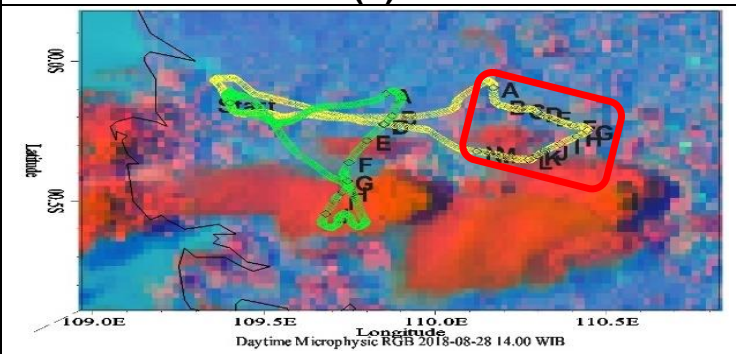

(c)

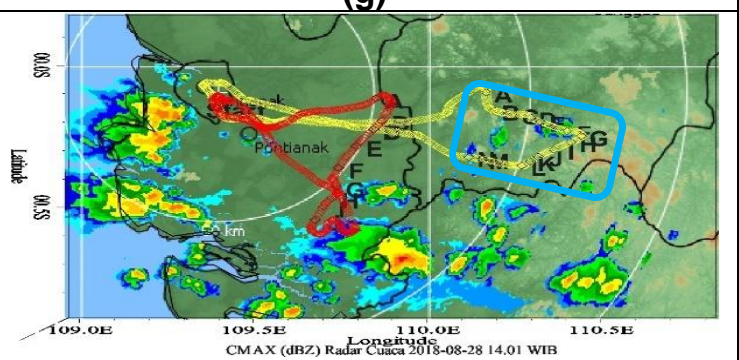

(h)

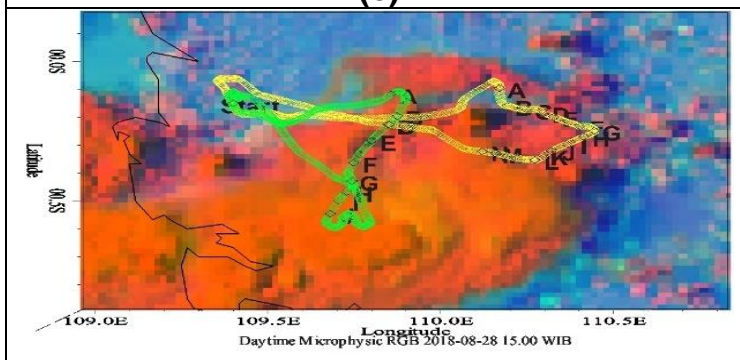

(d)

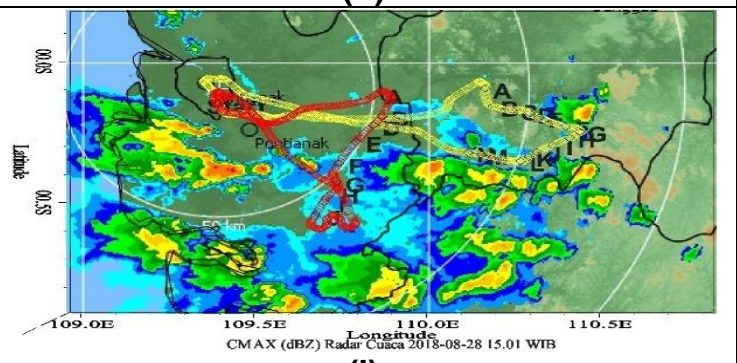

(i)
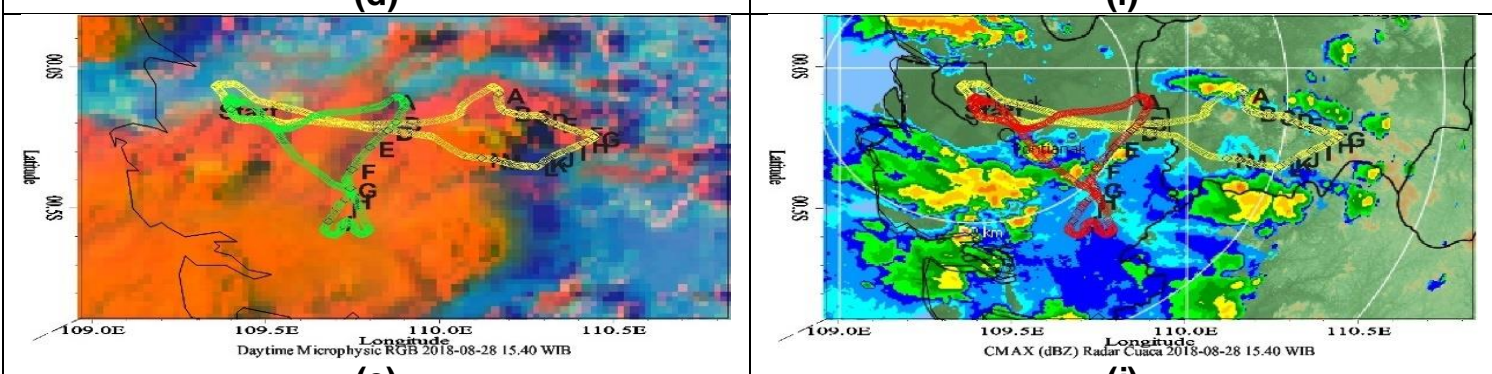

(j)

Gambar 7. Kondisi awan pada kegiatan TMC tanggal 28 Agustus 2018 yang terdeteksi dari

(a)-(e) produk daytime microphysic RGB Himawari 8; sedangkan (f)-(i) produk cmax radar cuaca.

(Keterangan warna RGB dijelaskan pada gambar 3 , keterangan warna CMAX terletak di kanan gambar, garis warna kuning adalah track pesawat pada sorti 1, sedangkan garis hijau/merah adalah track pesawat pada sorti 2, huruf A-J merupakan koordinat pesawat saat menebarkan bahan semai)

\subsection{Analisis Distribusi Awan pada TMC Tanggal 29 Agustus 2018}

Pada kegiatan TMC tanggal 29 Agustus 2018, berdasarkan tabel 5 pesawat lepas landas sekitar pukul 13.34 WIB. Di saat yang bersamaan, berdasarkan citra daytime microphysic RGB pada gambar 8(b) di wilayah koordinat penyemaian A$M$, terlihat adanya awan-awan tebal hasil peluruhan dari awan konvektif tebal yang bergerak di sebelah timur koordinat A-I mendekati koordinat semai. Sedangkan di wilayah sebelah barat laut rute semai, telah terlihat adanya awan cumulonimbus fase dewasa seperti karakteristik pada gambar 3 dimana pada fase ini selain terdapat updraft, juga terdapat downdraft sehingga kemungkinan sedang terjadi hujan. Hal ini terlihat juga pada gambar 8(e), dimana produk 
cmax radar menunjukkan adanya nilai 40-55 dbz. Di depan atau di sebelah timur awan cumulonimbus tersebut terdapat kumpulan cumulus potensial yang akan tumbuh menjadi cumulonimbus baru, yang mana jika dilihat dari deret waktu citra sebelumnya, menandakan cluster awan cumulonimbus tersebut akan terlihat bergerak mendekati rute semai.

Jika dibandingkan antara gambar 8(b) dan $8(e)$, terlihat ada pergeseran lokasi antara citra satelit dan radar yang disebut paralaks satelit karena awan cumulonimbus memiliki puncak awan yang sangat tinggi. Paralaks ini juga terjadi pada jam saat pesawat menebarkan bahan semai pada koordinat $A$ sampai $M$ yang diwakili oleh gambar 8(c) dan 8(f). Berdasarkan citra satelit tersebut, terlihat cluster awan cumulonimbus masih belum memasuki rute semai, hal ini berbeda dengan yang terlihat dari citra radar yang menunjukkan adanya awan cumulonimbus dengan nilai echo 35-55 dBz.

Berdasarkan citra daytime microphysic RGB sebelum pesawat take off, awan cumulus potensial terdeteksi mulai jam 11.00 WIB di sekitar koordinat semai $\mathrm{A}-\mathrm{N}$ seperti yang terlihat pada gambar 8(a), namun belum terdeteksi pada citra radar cuaca (gambar $8(d)$ ). Selain itu pada jam
11.00 WIB ini juga telah terdeteksi dari satelit dan radar, lokasi awal dari awan cumulonimbus yang telah dipaparkan sebelumnya dimana terletak di atas pesisir pantai sebelah barat laut dari rute semai.

Tabel 5. Koordinat Pesawat saat Melakukan

Penyemaian Tanggal 29 Agustus 2018

\begin{tabular}{|l|c|l|l|c|}
\hline $\begin{array}{c}\text { Way } \\
\text { point }\end{array}$ & Tanggal & $\begin{array}{c}\text { Jam } \\
\text { (WIB) }\end{array}$ & Lintang & Bujur \\
\hline Start & 29 -Aug-2018 & $13: 34$ & -0.151 & 109.406 \\
\hline A & 29 -Aug-2018 & $14: 25$ & 0.598 & 109.775 \\
\hline B & $29-A u g-2018$ & $14: 26$ & 0.562 & 109.747 \\
\hline C & $29-A u g-2018$ & $14: 27$ & 0.526 & 109.729 \\
\hline D & $29-A u g-2018$ & $14: 28$ & 0.485 & 109.718 \\
\hline E & $29-A u g-2018$ & $14: 29$ & 0.450 & 109.716 \\
\hline F & $29-A u g-2018$ & $14: 30$ & 0.396 & 109.729 \\
\hline G & $29-A u g-2018$ & $14: 32$ & 0.323 & 109.712 \\
\hline H & $29-A u g-2018$ & $14: 33$ & 0.273 & 109.713 \\
\hline I & $29-A u g-2018$ & $14: 34$ & 0.240 & 109.693 \\
\hline J & $29-A u g-2018$ & $14: 39$ & 0.026 & 109.732 \\
\hline K & $29-A u g-2018$ & $14: 40$ & 0.014 & 109.693 \\
\hline L & $29-A u g-2018$ & $14: 42$ & 0.037 & 109.644 \\
\hline M & $29-A u g-2018$ & $14: 43$ & 0.041 & 109.601 \\
\hline Finish & 29 -Aug-2018 & $15: 00$ & -0.149 & 109.403 \\
\hline
\end{tabular}

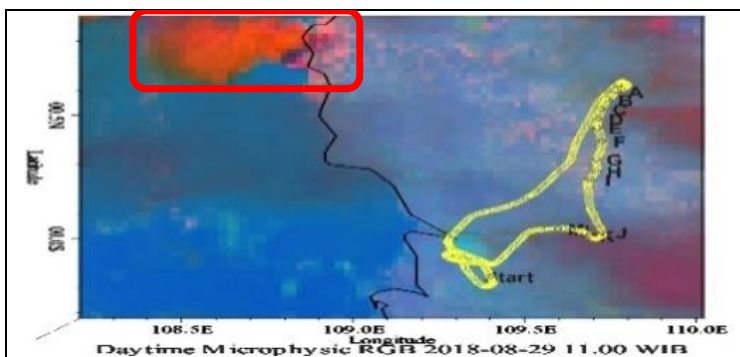

(a)

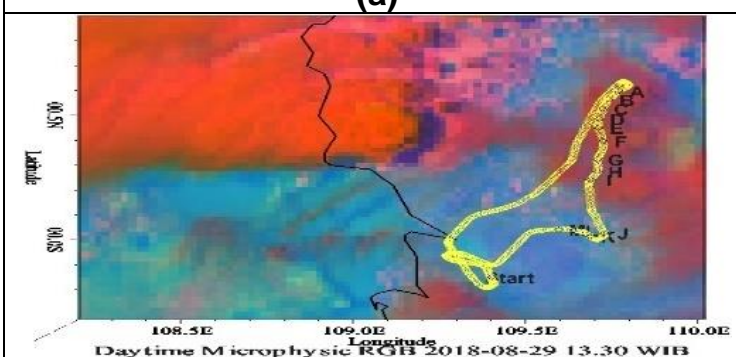

(b)

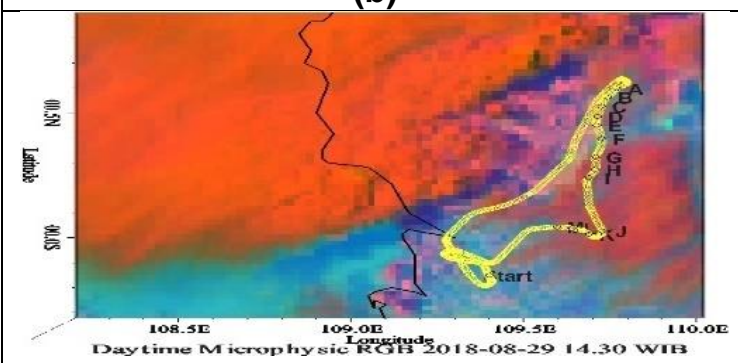

(c)

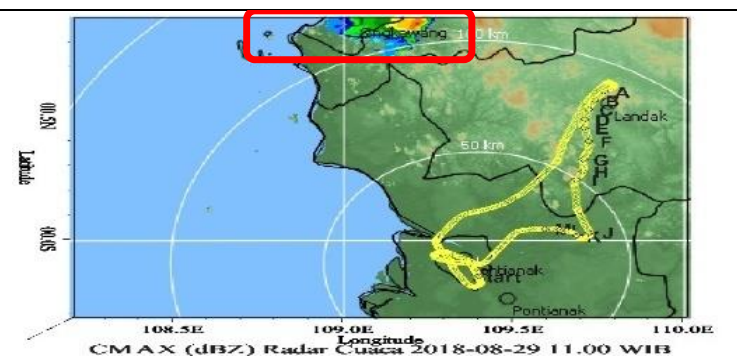

(d)

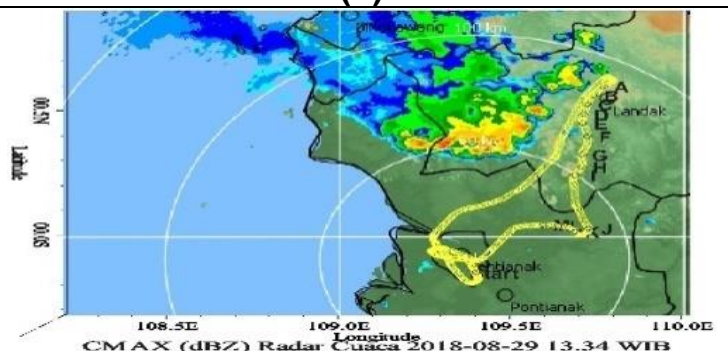

(e)

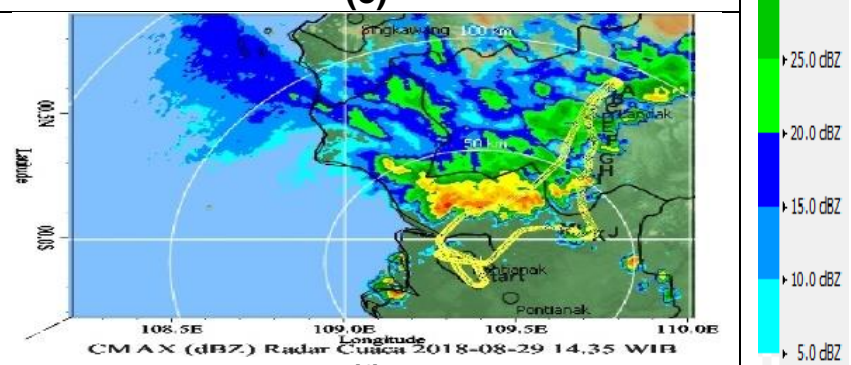

(f)

Gambar 8. Kondisi awan pada kegiatan TMC tanggal 29 Agustus 2018 yang terdeteksi dari

(a)-(c) produk daytime microphysic RGB Himawari 8; sedangkan (d)-(f) produk cmax radar cuaca. (Keterangan warna RGB dijelaskan pada gambar 3, keterangan warna CMAX terletak di kanan gambar) 


\subsection{Analisis Distribusi Awan pada TMC Tanggal 30 Agustus 2018}

Pada kegiatan TMC tanggal 30 Agustus 2018 ini, di tabel 6 menunjukkan pesawat lepas landas sekitar pukul 14.41 WIB. Di saat yang bersamaan, berdasarkan citra daytime microphysic RGB pada gambar 9 (b) di wilayah koordinat penyemaian $\mathrm{A}-\mathrm{Q}$, terlihat adanya awanawan cumulus potensial. Hal ini berbeda jika melihat dari citra produk cmax radar cuaca pada gambar 8(e), dimana terlihat satu sel awan konvektif dengan nilai echo sekitar $25 \mathrm{dBz}$.

Kondisi awan saat pesawat menebarkan bahan semai pada koordinat $A$ sampai $Q$ mulai jam 15.04-15.19 WIB seperti terlihat pada tabel 6 diwakili oleh gambar 9(c) dan 8(f) adalah masih berupa kumpulan awan cumulus potensial. Sedangkan jika dilihat dari citra cmax radar cuaca pada gambar 9(f), hanya terdapat nilai echo awan sebesar 10-15 dBz.

Berdasarkan analisis, citra daytime microphysic RGB pada periode sebelum pesawat take off, bahwa awan cumulus potensial mulai terdeteksi sekitar jam 12.00 WIB di titik koordinat semai $A-Q$ seperti yang terlihat pada gambar 9 (a). Namun awan cumulus potensial ini belum terdeteksi pada citra radar cuaca pada gambar $9(d)$.

Berdasarkan deret waktu citra daytime microphysics RGB mulai dari cumulus potensial terdeteksi hingga saat pesawat terbang untuk melakukan penyemaian yang diwakili oleh gambar 9(a)-9(c), terlihat di wilayah koordinat A-
Q hanya terlihat kumpulan awan cumulus potensial. Hal ini menunjukkan awan cumulus yang tumbuh tidak sampai bertambah tingginya yang menandakan pertumbuhan tidak berjalan sempurna. Kumpulan awan cumulus potensial ini ini bisa terdeteksi oleh citra cmax radar cuaca seperti pada gambar $9(\mathrm{~d})-9(\mathrm{f})$

Tabel 6. Koordinat Pesawat saat Melakukan Penyemaian Tanggal 30 Agustus 2018.

\begin{tabular}{|c|c|c|c|c|}
\hline $\begin{array}{l}\text { Way } \\
\text { point }\end{array}$ & Tanggal & $\begin{array}{l}\text { Jam } \\
\text { (WIB) }\end{array}$ & Lintang & Bujur \\
\hline Start & 30-Aug-2018 & $14: 41$ & -0.181 & 109.413 \\
\hline A & 30-Aug-2018 & $15: 04$ & 0.592 & 109.305 \\
\hline$B$ & 30-Aug-2018 & $15: 05$ & 0.590 & 109.266 \\
\hline $\mathrm{C}$ & 30-Aug-2018 & 15:06 & 0.562 & 109.247 \\
\hline $\mathrm{D}$ & 30-Aug-2018 & $15: 07$ & 0.512 & 109.251 \\
\hline $\mathrm{E}$ & 30-Aug-2018 & $15: 08$ & 0.483 & 109.270 \\
\hline $\mathrm{F}$ & 30-Aug-2018 & $15: 08$ & 0.464 & 109.300 \\
\hline $\mathrm{G}$ & 30-Aug-2018 & 15:09 & 0.454 & 109.324 \\
\hline $\mathrm{H}$ & 30-Aug-2018 & 15:09 & 0.452 & 109.351 \\
\hline I & 30-Aug-2018 & $15: 11$ & 0.457 & 109.401 \\
\hline $\mathrm{J}$ & 30-Aug-2018 & $15: 12$ & 0.456 & 109.449 \\
\hline $\mathrm{K}$ & 30-Aug-2018 & $15: 15$ & 0.494 & 109.594 \\
\hline $\mathrm{L}$ & 30-Aug-2018 & $15: 16$ & 0.473 & 109.626 \\
\hline M & 30-Aug-2018 & $15: 17$ & 0.446 & 109.652 \\
\hline $\mathrm{N}$ & 30-Aug-2018 & $15: 17$ & 0.416 & 109.664 \\
\hline $\mathrm{O}$ & 30-Aug-2018 & $15: 18$ & 0.392 & 109.653 \\
\hline $\mathrm{P}$ & 30-Aug-2018 & $15: 19$ & 0.360 & 109.629 \\
\hline $\mathrm{Q}$ & 30-Aug-2018 & $15: 19$ & 0.372 & 109.609 \\
\hline Finish & 30-Aug-2018 & $15: 45$ & -0.181 & 109. \\
\hline
\end{tabular}

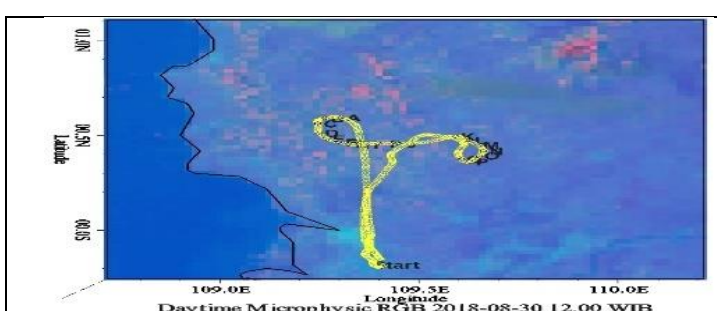

(a)

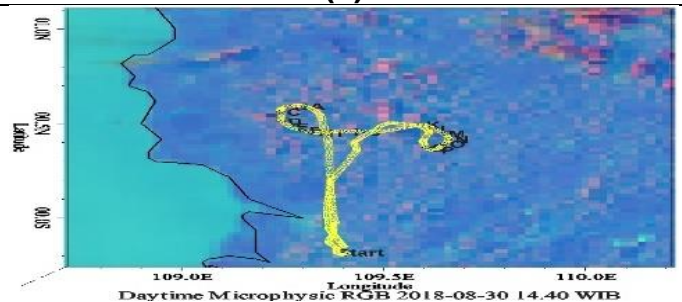

(b)

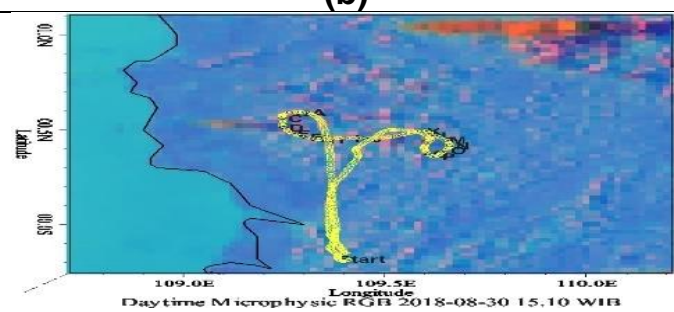

(c)

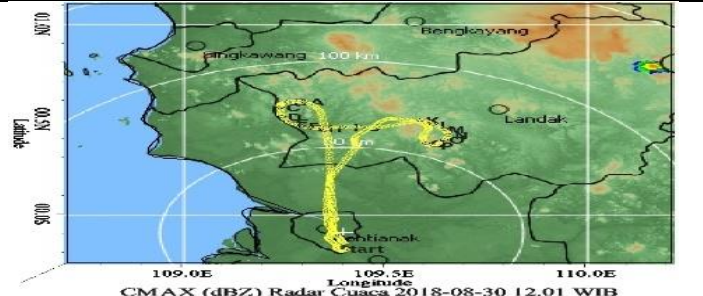

(d)

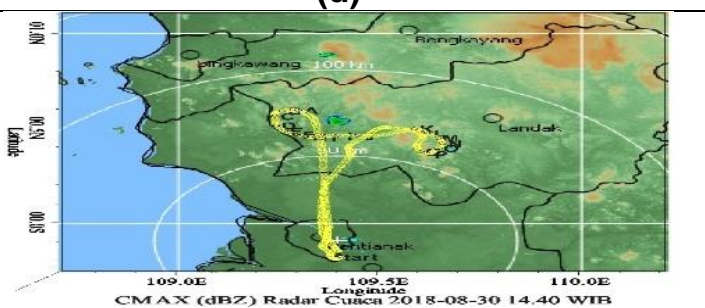

(e)

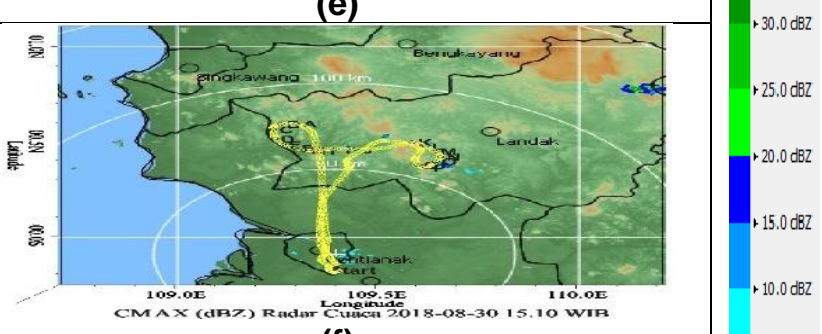

(f)

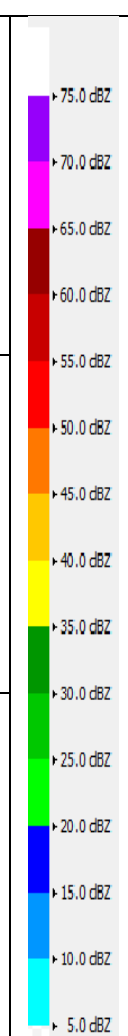

Gambar 9. Kondisi awan pada kegiatan TMC tanggal 30 Agustus 2018 yang terdeteksi dari

(a)-(c) produk daytime microphysic RGB Himawari 8; sedangkan (d)-(f) produk cmax radar cuaca.

(Keterangan warna RGB dijelaskan pada gambar 3, keterangan warna CMAX terletak di kanan gambar) 


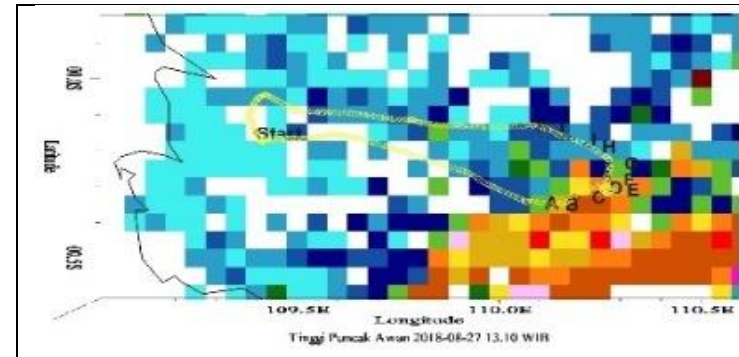

(a)

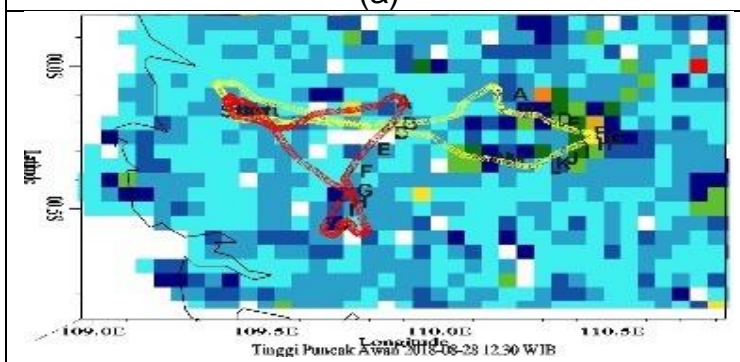

(b)

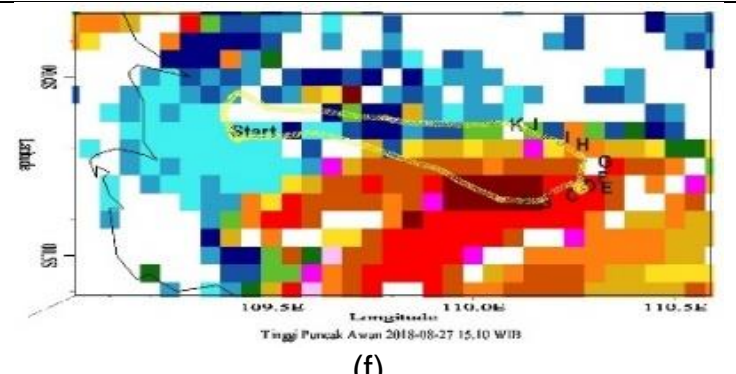

(f)

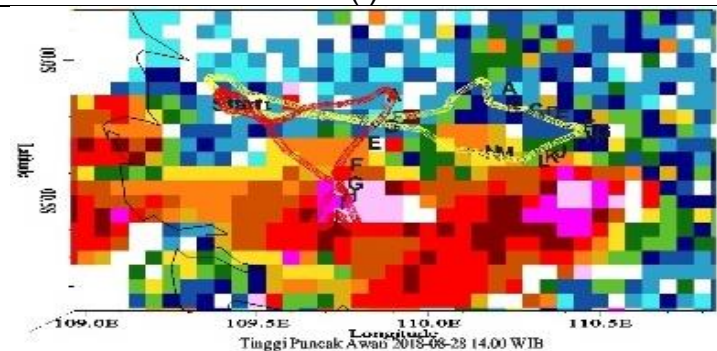

(g)

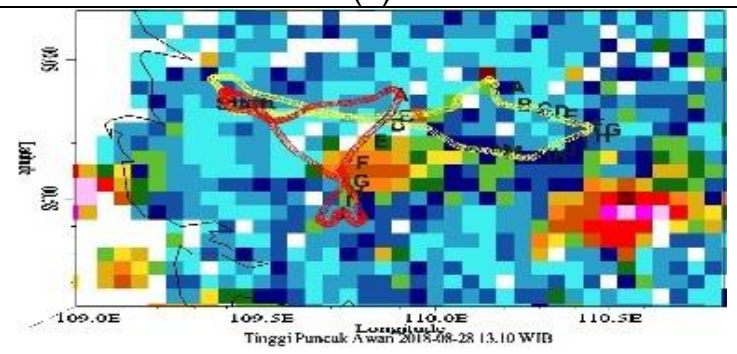

(c)

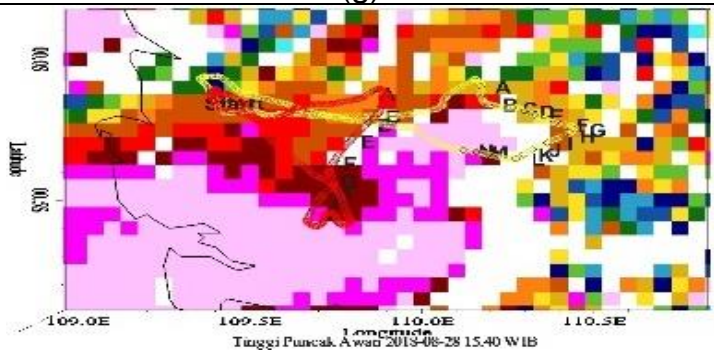

(h)

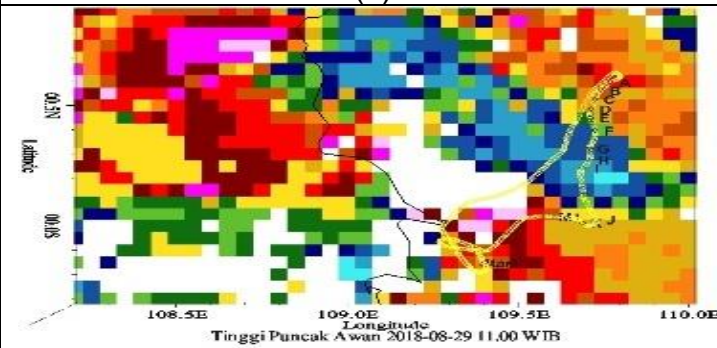

(d)

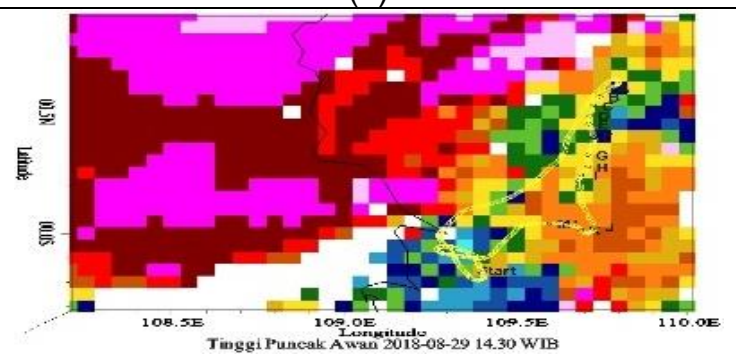

(i)

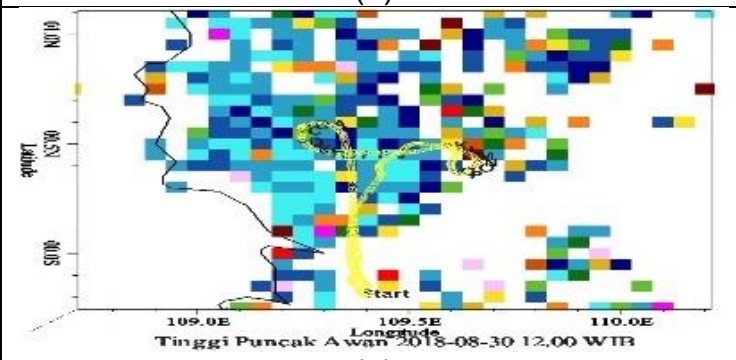

(e)

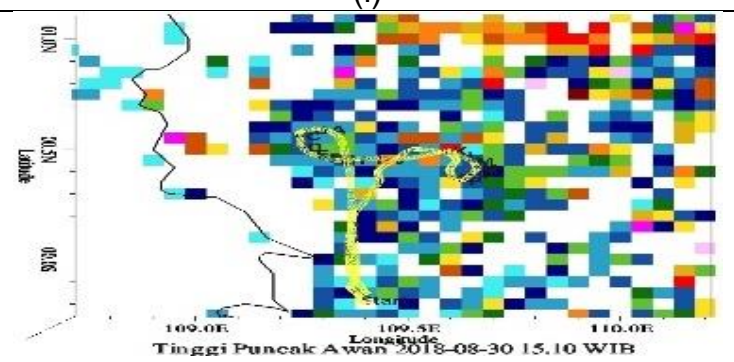

(j) $\mathrm{km}$ 17

15

13

11

9

3

1

Gambar 10. Tinggi puncak awan Satelit Himawari 8 sebelum take off (kiri) dan setelah dilakukan penyemaian (kanan).

Berdasarkan pembahasan studi kasus pada 4 hari pelaksaan kegiatan Teknologi Modifikasi Cuaca (TMC) di wilayah Kalimantan Barat, terlihat bahwa hampir sebagian besar awan-awan yang terdeteksi saat pesawat TMC lepas landas (take off) dan saat pesawat sedang melakukan penyemaian, awan sudah merupakan awan konvektif dengan tipe cumulonimbous yang memiliki ketinggian puncak awan yang sangat tinggi. Hal ini terlihat dari citra produk daytime microphysic RGB satelit, CMAX radar cuaca, dan citra ketinggian puncak awan seperti pada gambar 6(c), 6(f), dan 10(f) untuk tanggal 27 Agustus 2018; Gambar 7(c), 7(h), dan 10(g) untuk tanggal 28 Agustus 2018 sorti 1 serta gambar 7(e), 7(j), dan 10(h) untuk sorti 2; Gambar 8(c), 8(f), dan 10(i) untuk tanggal 29 Agustus 2018; Sedangkan untuk tanggal 30 Agustus 2018, pada saat pesawat take off dan melakukan penyemaian, terlihat masih terdeteksi awan cumulus potensial. Namun jika dianalisis citra satelit dan radar cuaca setelahnya, hingga menjelang malam tidak 
terdeteksi pertumbuhan awan cumulus potensial menjadi cumulonimbus seperti yang telah dijelaskan di sub bab 3.5

Sedangkan untuk kemunculan awan cumulus potensial dengan ketinggian 3-6 km yang terdeteksi di citra daytime microphysics RGB, tidak semuanya dapat terdeteksi melalui citra cmax radar cuaca. Hal ini seperti terlihat pada gambar 6(a), 6(d), dan 10(a) untuk tanggal 27 Agustus 2018; Gambar 7(a), 7(f), dan 10(b) untuk sorti 1 tanggal 28 Agustus 2018 serta gambar 7(b), 7(g), dan 10(c) untuk sorti 2; Gambar 8(a), 8(d), dan 10(d) untuk 29 Agustus 2018; Gambar 9(a) dan 9(d) untuk tanggal 30 Agustus 2018.

Tabel 7. Waktu Terbang Pesawat saat Melakukan Kegiatan TMC Tanggal 27-30 Agustus 2018

\begin{tabular}{|l|l|l|l|}
\hline \multirow{2}{*}{ Tanggal } & \multicolumn{3}{|c|}{ Waktu (WIB) } \\
\cline { 2 - 4 } & $\begin{array}{l}\text { Cumulus } \\
\text { potensial }\end{array}$ & $\begin{array}{l}\text { Take } \\
\text { off }\end{array}$ & Seeding \\
\hline $27 / 08 / 2018$ & 13.30 & 14.15 & 14.57 \\
\hline $28 / 08 / 2018$ Sorti 1 & 12.30 & 13.08 & 13.46 \\
\hline $28 / 08 / 2018$ Sorti 2 & 13.10 & 15.03 & 15.29 \\
\hline $29 / 08 / 2018$ & 11.00 & 13.34 & 14.25 \\
\hline $30 / 08 / 2018$ & 12.00 & 14.41 & 15.04 \\
\hline
\end{tabular}

Berdasarkan tabel 7, terlihat bahwa selang waktu antara terdeteksinya awan cumulus potensial dengan waktu take off maupun penyemaian jika menggunakan citra daytime microphysic RGB satelit himawari 8, bervariasi antara 1 hingga 2 jam. Hal ini menandakan bahwa pemanfaatan produk daytime microphysic RGB ini bisa mendeteksi lebih dini kemunculan awan cumulus potensial yang merupakan target kegiatan modifikasi cuaca. Hal ini bisa melengkapi pemanfaatan citra radar cuaca untuk panduan menemukan wilayah cumulus potensial, maupun citra kombinasi multi kanal satelit yang telah dikaji oleh Syaifullah \& Nuryanto (2016).

\section{KESIMPULAN}

Berdasarkan hasil penelitian, terlihat bahwa terdapat karakter awan cumulus potensial seperti yang ditunjukkan oleh hasil klasifikasi dari skema daytime microphysics RGB Himawari 8 pada rute semai pesawat TMC. Selain itu, selama 4 hari kegiatan TMC, terlihat bahwa skema daytime microphysics RGB Himawari 8 bisa mendeteksi awal kemunculan awan cumulus potensial dengan selang waktu 1 hingga 2 jam lebih awal sebelum pesawat TMC terlihat sampai ke lokasi awan cumulus potensial tersebut. Sehingga, skema daytime microphysics RGB Himawari 8 bisa dicoba sebagai pendeteksi awan cumulus potensial sebagai pelengkap data radar cuaca dalam kegiatan TMC. Selain sebagai alat deteksi, data satelit juga dapat dicoba sebagai alat evaluasi penerbangan penyemaian awan dengan melihat perubahan kondisi properti atau mikrofisis melalui produk daytime microphysics RGB. Hal ini untuk melengkapi analisis data radar cuaca terhadap pertumbuhan sel awan secara horizontal dan vertikal. Walaupun begitu, produk satelit masih memiliki kelemahan paralaks satelit, namun dengan mengetahui koreksi paralaks pada suatu daerah, kelemahan ini masih bisa diminimalisir.

\section{DAFTAR PUSTAKA}

Arifian, J. (2002). Kajian Kegiatan Modifikasi Cuaca di Catchment Area Towuti, Sulawesi Selatan. Jurnal Sains \& Teknologi Modifikasi Cuaca, 3(2), 83-89.

Comet (2013). Multispectral Satellite Aplications: RGB Product Explained. (https://www.meted.ucar.edu/training_mod ule.php?id=568\#.XjoJz3duLg8)

Harsoyo, B. (2012). Pemanfaatan Teknologi Modifikasi Cuaca untuk Penanggulangan Bencana Asap Kebakaran Lahan dan Hutan. Jurnal Sains \& Teknologi Modifikasi Cuaca, 13(2), 47-50. doi: 10.29122/jstmc.v13i2.2571

Haryanto, U. (2000). Teknologi Modifikasi Cuaca yang Efektif dan Efisien. Jurnal Sains \& Teknologi Modifikasi Cuaca, 1(1), 9-18.

JMA. (2015). Himawari User's Guide. (https://www.jmanet.go.jp/msc/en/support/index.html)

Lensky, M., Rosenfeld, D. (2008). CloudsAerosols-Precipitation Satellite Analysis Tool (CAPSAT). Atmospheric Chemistry and Physics, 8, 6739-6753. doi: 10.5194/acp-8-6739-2008

Renggono, F. (2015). Analisis Kemunculan Awan Hujan Berdasarkan Jenisnya untuk Mendukung Kegiatan Modifikasi Cuaca. Jurnal Sains \& Teknologi Modifikasi Cuaca, 16(2), 83-89. doi: 10.29122/jstmc.v16i2.1050

Seto, T.H. (2000). Peranan Bahan Semai Higroskopis dalam Penyemaian Awan. Jurnal Sains \& Teknologi Modifikasi Cuaca, 1(1), 19-26.

Syaifullah, M.D. (2011). Potensi Atmosfer dalam Pembentukan Awan Konvektif pada Pelaksanaan Teknologi Modifikasi Cuaca di DAS Kotopanjang dan DAS Singkarak 2010. Jurnal Sains \& Teknologi Modifikasi Cuaca, 12(1), 9-16. doi: 10.29122/jstmc.v12i1.2185

Syaifullah, M.D. (2012). Penerapan Teknologi Modifikasi Cuaca (TMC) untuk Mengatasi Defisit Inflow PLTA Bakaru Periode 15 Februari s.d 03 Maret 2012. Jurnal Sains \& Teknologi Modifikasi Cuaca, 13(1), 25-34. doi: 10.29122/jstmc.v13i1.2207

Syaifullah, M.D., Nuryanto, S. (2016). Pemanfaatan Data Satelit GMS Multi Kanal untuk Kegiatan Teknologi Modifikasi Cuaca. Jurnal Sains \& Teknologi Modifikasi 
Cuaca, 17(2), 47-55. doi: Wirahma, S., Seto, T.H., Athoillah, I. (2014). 10.29122/jstmc.v17i2.525

Tanaka, Y. (2009). SATAID-Powerful Toolfor Satellite Analysis. RSMC Tokyo-Typhoon Center, Japan Meteorology Agency (JMA). Pemanfaatan Teknologi Modifikasi Cuaca untuk Perkebunan Kelapa Sawit. Jurnal Sains \& Teknologi Modifikasi Cuaca, 15(1), 39-47. doi: 10.29122/jstmc.v15i1.2656

Wallace, J.M., Hobbs, P.V. (2005). Atmospheric Science: An Introductory Survey, $2^{\text {nd }}$ edition. Washington: Elsevier. 